\title{
OPEN Experimentally measured methane hydrate phase equilibria and ionic liquids inhibition performance in Qatar's seawater
}

\author{
M. F. Qureshi' ${ }^{1}$, M. Khraisheh ${ }^{2 \bowtie}$ \& F. AlMomani ${ }^{2}$
}

Qatar has the third-largest natural gas reserves in the world and is the second largest Liquefied natural gas (LNG) exporter in the world. These reserves are mainly located in its offshore North Field where the gas is extracted, transported to the onshore units, and is converted to LNG for international export. The formation of natural gas hydrates in the offshore subsea lines can cause unwanted blockages and hinder the smooth supply of gas supply from offshore to onshore units. In the present work, the formation and dissociation of methane gas hydrates have been studied in the ultra pure water system (UPW), artificial seawater (ASW), and Qatar seawater (OSW) at different conditions (4-10 MPa) using standard rocking cell rig. The naturally occurring seawater was collected from Ras Laffan seacoast located in Doha, Qatar. The seawater sample was examined for elemental analysis $\left(\mathrm{SO}_{4}, \mathrm{Cl}, \mathrm{Na}, \mathrm{Ca}, \mathrm{Mg}, \mathrm{K}\right.$, and $\mathrm{Fe}$ ) using inductively coupled plasma atomic emission spectroscopy (ICP-AES) technique and its other properties like density, electrical conductivity, and $\mathrm{pH}$ were also measured. The experimental results show that the $\mathrm{CH}_{4}$ pure water $\mathrm{HLVE}$ curve is suppressed by about $3 \mathrm{~K}$ in Qatar seawater and $2 \mathrm{~K}$ in artificial seawater. The hydrate inhibition strength of the lonic liquids (ILs) salts 3-Ethyl-1-methyl-1H-imidazol-3-ium methane-sulfonate $\left[\mathrm{C}_{7} \mathrm{H}_{14} \mathrm{~N}_{2} \mathrm{O}_{3} \mathrm{~S}\right]$ and 3-Ethyl-1methyl-1H-imidazol-3-ium dicyanoazanide $\left[\mathrm{C}_{8} \mathrm{H}_{11} \mathrm{~N}_{5}\right]$ was evaluated in both the ultra pure water and Qatar seawater systems. Their performance was compared with methanol and other ILs salts reported in the literature. The selected ILs exhibited poor hydrate inhibition effect in the ultra pure water systems, but they show a noticeable thermodynamic and kinetic hydrate inhibition effect in the Qatar seawater system. The computational 3D molecular models of ILs and methanol were generated to cognize the plausible hydrate inhibition mechanism in the presence of these inhibitors.

Gas hydrates are crystalline solid compounds that are formed when small molecules like methane and ethane get trapped within water molecules under high pressure and low-temperature conditions ${ }^{1}$. The naturally occurring gas hydrates are a great source of energy ${ }^{2}$ that can store gas at high density, but the formation of gas hydrates in the subsea pipelines and deepwater drilling equipment post a serious threat to offshore flow assurance as they can lead to unwanted blockages in offshore subsea lines and interrupt the offshore operations ${ }^{3-5}$. Therefore, it's essential to have effective hydrate mitigation for smooth and safe offshore operations for oil and gas sector ${ }^{6,7}$.

Qatar is reported to possess the third-largest natural gas reserves in the world and is also the largest exporter of the liquefied natural gas in the globe ${ }^{8}$. The LNG trade demands a consistent supply of gas from offshore to onshore units and the formation of gas hydrates can hinder this supply. The water that exists in the subsea lines is likely to be saline in nature, it's essential to understand the characteristics of hydrate formation and dissociation dynamics in the actual seawater system to develop an effective hydrate mitigation strategy, and select the right set of chemical hydrate inhibitors ${ }^{9}$. Generally, the chemical hydrate inhibitors are classified as thermodynamic hydrate inhibitors $(\mathrm{THI})^{10}$, kinetic hydrate inhibitors (KHI $)^{11}$, and anti-agglomerates (AA) ${ }^{12}$. Thermodynamic hydrate inhibitors like methanol and mono-ethylene glycol are widely used in the industry for hydrate prevention $^{10}$. These hydrate inhibitors function well, but they are required in bulk quantities $(>30 \mathrm{wt} \%)^{13}$, and there are environmental and safety concerns associated with the disposal of these chemicals ${ }^{14}$. Therefore, over the last decade, the research interest has shifted towards the KHI that required in much lower quantity $(\leq 5 \mathrm{wt} \%)^{15}$.

${ }^{1}$ Department of Chemical and Biomolecular Engineering, National University of Singapore, Singapore, Singapore. ${ }^{2}$ Department of Chemical Engineering, Qatar University, Doha, Qatar. ${ }^{\square}$ email: m.khraisheh@ qu.edu.qa 
The Ionic liquids (ILs) are a new class of low dosage hydrate inhibitors (LDHI) that have been already used for carbon capture ${ }^{16,17}$, wastewater treatment ${ }^{18}$, desalination ${ }^{19,20}$, and gas separation ${ }^{21}$. The ILs offer a potential substitute for carbon capture and storage because of their negligible vapor pressure and high thermal stability, which reduces solvent losses 22,23 . Some classes of ILs are reported to be environmentally friendly and tend to act as both THI and $\mathrm{KHI}^{24-30}$. By making simple changes in the structure of anion or the cation, properties like solubility, density, reflective index and viscosity of ILs can be adjusted to suit the process requirements ${ }^{31,32}$. This makes them an ideal inhibitor to be used for hydrate prevention and other processes. In addition, they can be designed for a special application by tuning of cation, anion and functional groups ${ }^{33,34}$. However, there are main concerns about their economic feasibility on large commercial scale and now some research is being diverted towards other compounds like amino acids ${ }^{35}$.

Rouher and Barduhn ${ }^{36}$, were among the first groups to work with seawater and they published gas hydrate equilibrium data in seawater to design a desalination process using iso-butane hydrates. Ohgaki et al. ${ }^{37}$, studied the $\mathrm{CO}_{2}$ hydrate formation in the seawater and the pure water. Englezos and Bishnoi ${ }^{38}$, developed a model for predicting water activity and methane hydrate stability conditions in artificial seawater. Similarly, Dholabhai et al. ${ }^{39}$ studied hydrate formation and equilibrium conditions in synthetic seawater using methane, propane, and carbon dioxide. At different salinity levels Tishchenko et al. ${ }^{40}$, developed a model for predicting methane hydrate equilibrium curves. The methane hydrate dissociation conditions with $\mathrm{NaCl}$ solutions was experimentally demonstrated by Maekawa et al. ${ }^{41}$ Whereas, Dickens and Quinby-Hunt ${ }^{42}$, reported the methane hydrate stability conditions in the seawater with the salinity of up to $33.5 \%$ and observed that the methane hydrate dissociation temperature is depressed by almost $-1.1^{\circ} \mathrm{C}$ in the seawater system compared to the pure water system. Yang and $\mathrm{Xu}^{43}$, studied the effect of salinity on methane gas hydrate system and their numerical modeling results show that the methane hydrate zone gets shallower with the rise in the salinity and the stability of hydrate crystals is also reduced. In addition to that, they also stated that the presence of some salts in the seawater system can also promote the actual hydrate crystal formation in the hydrate stability zone. Li et al. ${ }^{44}$, reported phase equilibrium conditions of $\mathrm{CH}_{4}$ hydrate in $3.5 \mathrm{wt} \% \mathrm{NaCl}, \mathrm{KCl}, \mathrm{CaCl}_{2}$ and $\mathrm{MgCl}_{2}$ solutions experimentally investigated at the temperature-pressure ranges of 281.9-287.1 K and 7.33-14.02 MPa. They also proposed a model based on the Chen-Guo model and the Hu-Lee-Sum (HLS) correlation for hydrate prediction. Their experimental outcomes show that the inhibition effect of $\mathrm{MgCl}_{2}$ is more significant than that of other salts. Hu et al. ${ }^{45}$, investigated the aptness of the Hu-Lee-Sum (HLS) correlation to calculate structure I hydrates and structure II hydrates depression temperature in any single salt or mixed salt-gas systems. According to them, the Hu-Lee-Sum (HLS) correlation, with introduction of certain parameters, is able to predict the hydrate depression temperature for complex gas and salt mixtures. Khan et al. ${ }^{46}$, carried out hydrate formation experiments using methane + ethane (74.7/25.3 mol\%) gaseous mixtures and indicated that the formation onset times were three times longer in salt water compared to fresh water. Husebø et al. ${ }^{47}$ reported, that the hydrates stability in the reservoir relies on various factors which include interaction between minerals and nearby fluids. Normally, the salinity level increases with the depth in the reservoir and the formation of hydrate in the saline environment may increase the salinity level of the fluid surrounding the formed hydrate ${ }^{47}$. Due to this factor, the hydrates formed in the saline environment tend to be very non-uniform and may also lead to liquid pockets of the residual aqueous solution with high salinity ${ }^{47}$.

In this work the $\mathrm{CH}_{4}$ hydrate dissociation points in ultra pure water system (UPW) was compared with $\mathrm{CH}_{4}$ hydrate dissociation points in artificial seawater (ASW), Qatar seawater (QSW) and other saline water systems reported in the literature. The $\mathrm{CH}_{4}$ gas was chosen for easier comparison with literature data. The novelty aspect of this work is the use of Qatar seawater to experimentally investigate $\mathrm{CH}_{4}$ hydrate formation and dissociation at diverse conditions (4-12 MPa). The hydrate inhibition performance of the Ionic liquids (ILs) salts $\mathrm{C}_{7} \mathrm{H}_{14} \mathrm{~N}_{2} \mathrm{O}_{3} \mathrm{~S}$ and $\mathrm{C}_{8} \mathrm{H}_{11} \mathrm{~N}_{5}$ was evaluated in the ultra pure water system and Qatar seawater systems at different pressure conditions (4-12 $\mathrm{MPa}$ ) and their performance was compared with industrial thermodynamic inhibitor methanol and other ILs salts reported in the literature. All the experiments were conducted in the standard rocking cell rig (RC-5) installed at the Qatar University. The 3D computational models of selected ILs and methanol were generated to conceptualize the plausible inhibition mechanism.

\section{Experimental section}

Material and samples. The pure methane $\left(\mathrm{CH}_{4}\right)$ gas with a purity of $99.9 \%$ was purchased from Buzware Scientific and Technical Gases, Doha (Qatar). The list of ILs and other chemicals used for the experiments is shown in Table 1. These chemicals were purchased from Sigma Aldrich USA and IoLiTec Germany with purity (>98\%). The fresh seawater sample was obtained from the bay closer to the Ras Laffan Industrial City Qatar. The sample was analyzed for $\mathrm{pH}, \mathrm{EC}$, and element detection using Thermo Orion Versa Star Pro Multiparameter Benchtop Meter, Thermo Scientific iCAP 6500-ICP-OES Spectrometer, respectively. The elemental content analysis of the seawater sample is shown in Table 2. All the ILs sample solutions were prepared with ultra pure water at room temperature using an electronic balance with a precision of $\pm 0.0001 \mathrm{~g}^{48}$.

High-pressure apparatus and procedures. The methane phase equilibria (HLVE) or hydrate dissociation points were obtained in ultra pure water system (UPW), artificial seawater (ASW) and Qatar Seawater (QSW) using the standard rocking cell assembly (RC-5) provided by PSL SystemtechniK GmbH (Fig. 1), located in Chemical Engineering lab at Qatar University in 2018 (Tables 3, 4 and 5). It consists of 5 stainless steel (AISI 316L) made cells that are attached to the same skid that rocks the cells and are operated simultaneously. The system is able to bear up to $20 \mathrm{MPa}$ pressure and within the temperature range of -263 to $333 \mathrm{~K}$. The temperature sensors have the accuracy of $\pm 0.01^{\circ} \mathrm{K}$ and pressure sensors have an accuracy of $0.1 \%$. The combined standard uncertainty for the experiments was found to be less than $<1 \%$. The temperature and pressure values with time were recorded during the experiment run with help of pre-installed specialized software by PSL. A diluted 


\begin{tabular}{|c|c|c|c|}
\hline Ionic Liquids (ILs) & Molecular Structure & $\begin{array}{l}\text { Molecular } \\
\text { Weight }\end{array}$ & Molar Formula \\
\hline $\begin{array}{l}\text { 3-Ethyl-1-methyl-1H- } \\
\text { imidazol-3-ium } \\
\text { methane-sulfonate }\end{array}$ & & $206.27 \mathrm{~g} / \mathrm{mol}$ & $\mathrm{C}_{7} \mathrm{H}_{14} \mathrm{~N}_{2} \mathrm{O}_{3} \mathrm{~S}$ \\
\hline $\begin{array}{l}\text { 3-Ethyl-1-methyl-1H- } \\
\text { imidazol-3-ium } \\
\text { dicyanoazanide }\end{array}$ & & $177.21 \mathrm{~g} / \mathrm{mol}$ & $\mathrm{C}_{8} \mathrm{H}_{11} \mathrm{~N}_{5}$ \\
\hline Methanol & & $32.04 \mathrm{~g} / \mathrm{mol}$ & $\mathrm{CH}_{3} \mathrm{OH}$ \\
\hline Sodium Chloride & $\mathrm{Na}^{+} \mathrm{Cl}^{-}$ & $58.44 \mathrm{~g} / \mathrm{mol}$ & $\mathrm{NaCl}$ \\
\hline
\end{tabular}

Table 1. List of Ionic Liquids (ILs) used and their structures.

\begin{tabular}{|l|l|l|}
\hline Test & Result & Unit \\
\hline $\mathrm{pH}$ & 8.05 & \\
\hline $\mathrm{EC}$ & 64.93 & $\mathrm{mc} / \mathrm{cm}$ \\
\hline $\mathrm{SO}_{4}$ & 1500 & $\mathrm{ppm}$ \\
\hline $\mathrm{Cl}$ & 19,370 & $\mathrm{ppm}$ \\
\hline $\mathrm{Na}$ & 13,352 & $\mathrm{ppm}$ \\
\hline $\mathrm{Ca}$ & 484 & $\mathrm{ppm}$ \\
\hline $\mathrm{Mg}$ & 1477 & $\mathrm{ppm}$ \\
\hline $\mathrm{K}$ & 449 & $\mathrm{ppm}$ \\
\hline $\mathrm{Fe}$ & 8.76 & $\mathrm{ppm}$ \\
\hline $\mathrm{Sr}$ & 8.96 & $\mathrm{ppm}$ \\
\hline
\end{tabular}

Table 2. Content analysis of Qatar sea water sample.

inhibitor solution of sample $15 \mathrm{~cm}^{3}$ was added to each cell and the cells were carefully tightened and placed on a rocking skid that was submerged in a cooling bath. Then the loaded cells, immersed in the bath, were cooled from 293.15 to $275.15 \mathrm{~K}$ within $9 \mathrm{~h}$ at the cooling rate of $1.8 \mathrm{~K}$ per h. This step is followed by an isothermal step of $24 \mathrm{~h}$ at a fixed temperature of $275.15 \mathrm{~K}$ and then finally the cells were slowly heated at the rate of $0.1 \mathrm{~K}$ per $\mathrm{h}$ till the temperature reached back to $293.15 \mathrm{~K}$ (Fig. 2$)^{49}$. As the temperature is increased further the hydrate phase completely disappears. To maintain the accuracy experiments were performed 2-3 times to ensure the reliability of the results with different pressures by using the same protocol. The overall pressure drop ${ }^{50}$ during hydrate formation was monitored classically using pressure sensors. Figure 3, shows the repeated experimental trials for $\mathrm{CH}_{4} \mathrm{HLVE}$ and comparison of the experimental data with literature and simulation data. Table 3, shows the $\mathrm{CH}_{4}$ HLVE data points obtained using the rocking cell assembly for three experimental trials. The experimental results were found to be in good agreement with the literature data and the standard error in the repeated experiments was about $0.05 \mathrm{~K}$. More experimental procedures and equipment details have been reported in our previous works $s^{13,35,51-55}$. 


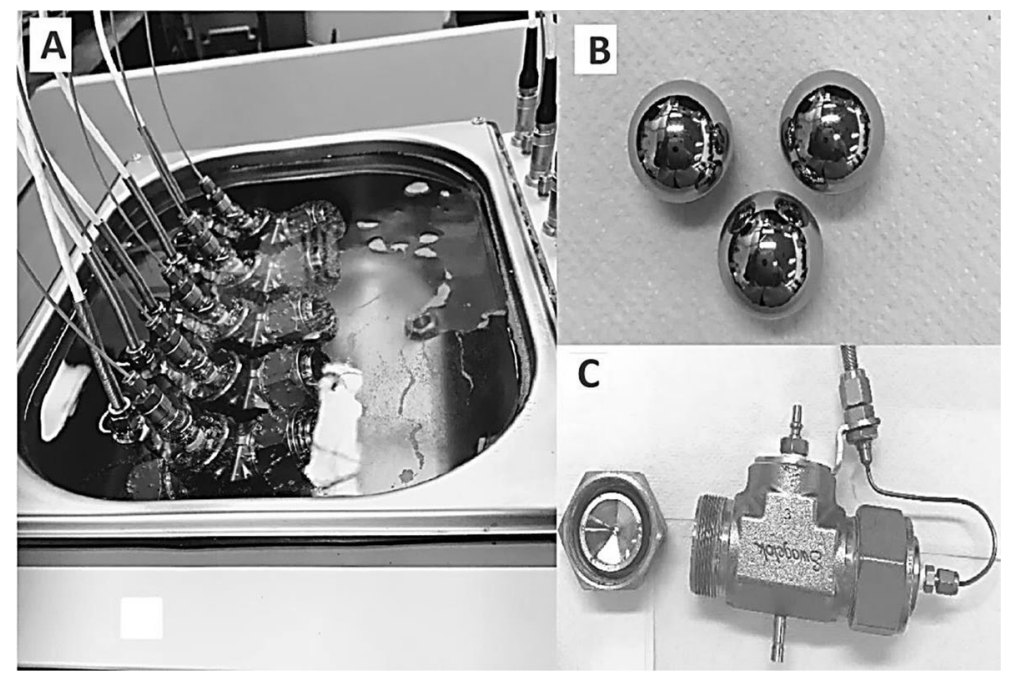

Figure 1. (A) Rocking Cell (RC-5) assembly used for the experiment, (B) stainless steel balls for agitation, and (C) stainless steel cell with screw cap.

\begin{tabular}{|l|l|l|l|l|l|}
\hline \multicolumn{3}{|l|}{ Trial 1 } & \multicolumn{2}{l|}{ Trial 2 } & \multicolumn{2}{l|}{ Trial 3 } \\
\hline T (K) & P (MPa) & T (K) & P (MPa) & T(K) & P(MPa) \\
\hline 287.12 & 11.40 & 287.68 & 11.91 & 287.48 & 11.92 \\
\hline 285.85 & 9.66 & 286.07 & 9.85 & 286.09 & 9.86 \\
\hline 283.67 & 7.52 & 281.82 & 6.10 & 282.02 & 6.13 \\
\hline 281.15 & 5.76 & 278.42 & 4.23 & 278.46 & 4.24 \\
\hline 277.25 & 3.87 & & & & \\
\hline
\end{tabular}

Table 3. Pure methane HLVE (hydrate liquid-vapor equilibrium) data points for three experimental trials.

\begin{tabular}{|c|c|c|c|c|}
\hline \multirow[b]{2}{*}{ Components } & \multicolumn{2}{|c|}{$\begin{array}{l}\text { Ultra pure water } \\
\text { system }\end{array}$} & \multicolumn{2}{|c|}{ Qatar sea water } \\
\hline & $\mathbf{T}(\mathbf{K})$ & P (MPa) & $\mathbf{T}(\mathbf{K})$ & $\mathbf{P}$ (MPa) \\
\hline \multirow{5}{*}{$\mathrm{CH}_{4}$} & 287.12 & 11.4 & 285.93 & 12.78 \\
\hline & 285.85 & 9.658 & 284.36 & 11.21 \\
\hline & 283.67 & 7.518 & 282.15 & 9 \\
\hline & 281.14 & 5.763 & 279.74 & 6.59 \\
\hline & 277.24 & 3.87 & & \\
\hline \multirow{5}{*}{$\mathrm{CH}_{4}+5 \mathrm{wt} \% \mathrm{C}_{7} \mathrm{H}_{14} \mathrm{~N}_{2} \mathrm{O}_{3} \mathrm{~S}$} & 287.16 & 11.77 & 285.31 & 11.23 \\
\hline & 285.7 & 9.83 & 283.92 & 9.42 \\
\hline & 283.8 & 7.89 & 281.71 & 7.71 \\
\hline & 281.28 & 5.89 & 280.98 & 6.74 \\
\hline & 278 & 4.1 & 279.57 & 5.72 \\
\hline \multirow{5}{*}{$\mathrm{CH}_{4}+5 w t \% \mathrm{C}_{8} \mathrm{H}_{11} \mathrm{~N}_{5}$} & 286.91 & 11.40 & 284.84 & 11.29 \\
\hline & 285.69 & 9.78 & 283.31 & 9.41 \\
\hline & 283.64 & 7.76 & 282.11 & 7.83 \\
\hline & 281.53 & 5.98 & 279.45 & 5.67 \\
\hline & 277.71 & 3.99 & & \\
\hline \multirow{4}{*}{$\mathrm{CH}_{4}+5 \mathrm{wt} \% \mathrm{MeOH}$} & 283 & 8.86 & 282.93 & 11 \\
\hline & 282 & 7.96 & 281.92 & 9.48 \\
\hline & 280 & 6.45 & 280.06 & 7.50 \\
\hline & 278 & 5.26 & 277.90 & 5.73 \\
\hline
\end{tabular}

Table 4. $\mathrm{CH}_{4} \mathrm{HLVE}$ (hydrate liquid-vapor equilibrium) data points obtained in the ultra pure water and Qatar seawater sample solutions in the presence of $5 \mathrm{wt} \%$ ionic liquid salts and $5 \mathrm{wt} \%$ methanol. The HLVE data for $5 \mathrm{wt} \%$ methanol in pure water system was obtained using CSMHYD ${ }^{61}$. 


\begin{tabular}{|l|l|}
\hline $\mathbf{T}(\mathbf{K})$ & $\mathbf{P}(\mathbf{M P a})$ \\
\hline 285.22 & 11.16 \\
\hline 284.25 & 10.01 \\
\hline 281.91 & 7.81 \\
\hline 281.01 & 6.75 \\
\hline 279.69 & 5.97 \\
\hline
\end{tabular}

Table 5. $\mathrm{CH}_{4} \mathrm{HLVE}$ (hydrate liquid-vapor equilibrium) data points experimentally obtained in the artificial sea water (ASW) $(5 \mathrm{wt} \% \mathrm{NaCl})$.

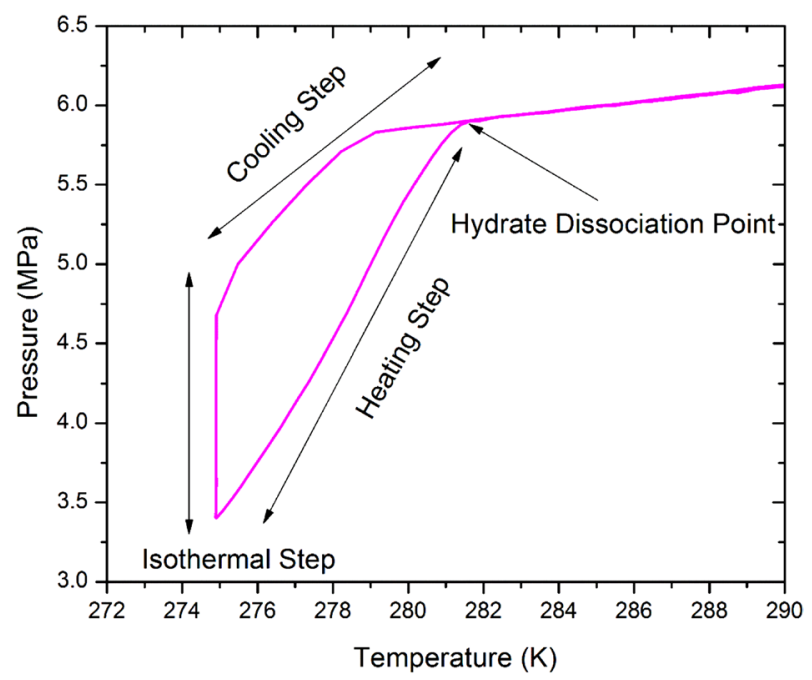

Figure 2. The experimental loop for a sample showing three experimental steps and the hydrate dissociation point.

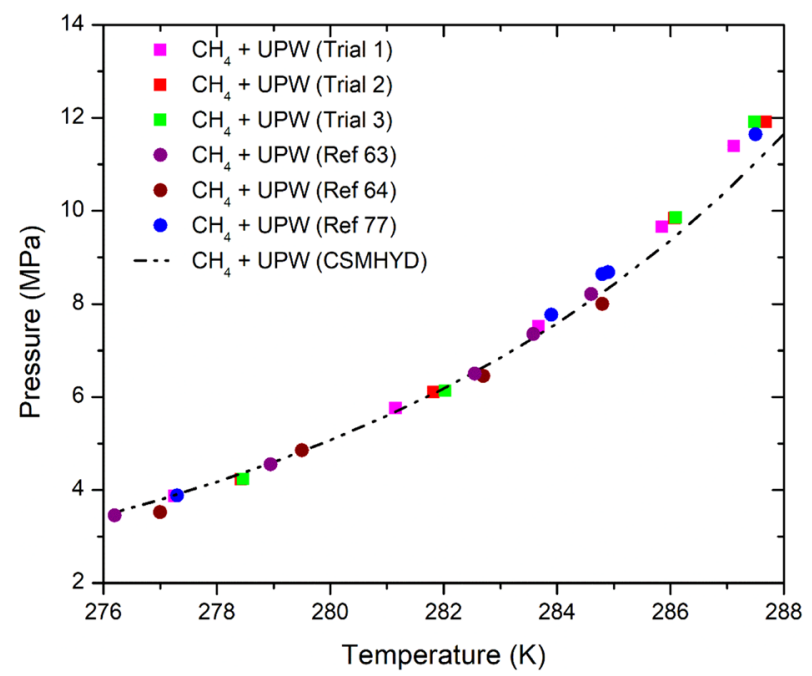

Figure 3. The repeated experimental trials for $\mathrm{CH}_{4}$ pure water HLVE and comparison of the ultra pure water experimental HLVE data with literature data Refs..$^{63,64,77}$ and the data is also compared with hydrate simulation package CSM Hydrate ${ }^{61}$. A good agreement was observed between experimental, literature and CSM Hydrate package data ${ }^{61}$. 


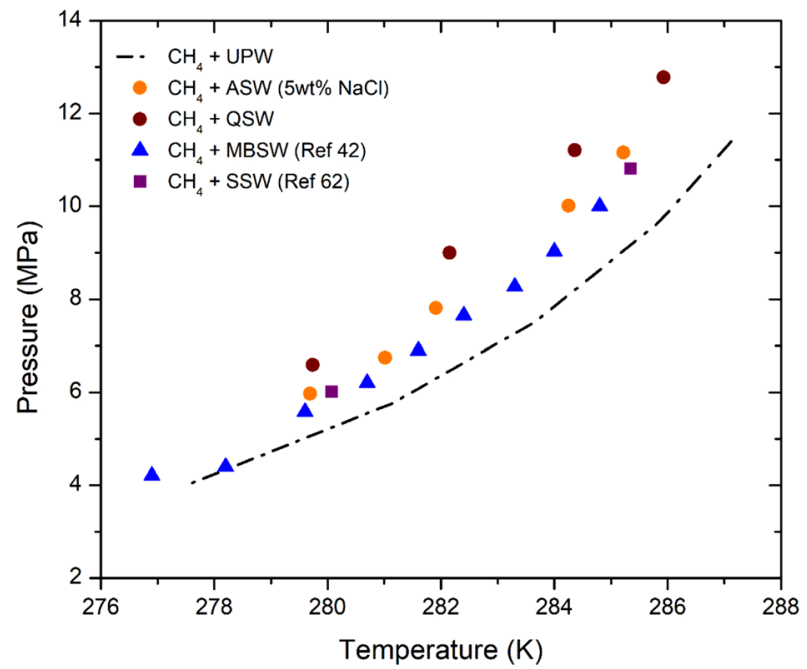

Figure 4. Comparing $\mathrm{CH}_{4}$ HLVE curve in ultra pure water (UPW) with artificial seawater (ASW), Qatar sea water (QSW), Monterey Bay (off the California coast US) Sea Water (MBSW) ${ }^{42}$ and Synthetic Sea Water $(\mathrm{SSW})^{62}$. The $\mathrm{CH}_{4}$ pure water HLVE curve was suppressed by $3 \mathrm{~K}$ in QSW, $2 \mathrm{~K}$ in ASW, $1.5 \mathrm{~K}$ in SSW and $1 \mathrm{~K}$ in MBSW. The experimental HLVE data of this work has the uncertainty of about $\pm 0.05 \mathrm{~K}$.

Extraction of gas hydrate dissociation and induction points. The extraction of accurate equilibrium point was conducted using the previously reported method by Tohidi et al. ${ }^{56}$. The gas hydrate dissociation point is extracted when the $\mathrm{H}-\mathrm{V}$ (hydrate-vapor) and the $\mathrm{H}-\mathrm{L}_{\mathrm{w}}-\mathrm{V}$ (hydrate-liquid-vapor) equilibrium lines intersect with each other ${ }^{57}$. The point noted where the two equilibrium points intersect that is called 'hydrate dissociation point' as illustrated in Fig. $2^{57}$. For kinetics, the hydrate formation or induction point is an interval where the first hydrate crystal sighted (formation) by a sharp pressure drop during the cooling process of the heating-cooling cycle ${ }^{53}$. The hydrate induction times were calculated using the pressure-time (P-t) curves plotted for a specific sample using the recorded experimental data. The hydrate induction has been defined in different ways based on their measurement techniques ${ }^{58,59}$. In this work, the hydrate induction or formation time is taken as the point where a sharp pressure decline occurs ${ }^{60}$. The detailed calculation procedure for the hydrate induction time has been reported in previous studies ${ }^{52,54}$. The uncertainty in the reported induction times is within the range of $\pm 0.3 \mathrm{~h}(20 \mathrm{~min})$. The temperature and pressure sensors were calibrated and the reliability of the results was checked by repeating the experiments (Table 2) and comparing the experimental data for the pure methane hydrate liquid-vapor equilibrium (HLVE) curve with the literature values and the simulation results (Fig. 3).

\section{Results and discussion}

Initially, the pure methane $\left(\mathrm{CH}_{4}\right)$ hydrate dissociation points (thermodynamics) and induction times (kinetics) were evaluated in a ultra pure water system at different pressure conditions (4-10 MPa). Then the same experiments were conducted using pure methane in the artificial seawater and Qatar seawater sample solutions at similar pressure conditions. Then the thermodynamic and kinetic hydrate inhibition effect of Ionic liquid (IL) salts and methanol was investigated in the ultra pure water and Qatar seawater systems both. Table 4, shows $\mathrm{CH}_{4}$ HLVE (Hydrate Liquid-Vapor Equilibrium) data points obtained in the ultra pure water and Qatar seawater sample solutions in the presence of $5 \mathrm{wt} \%$ ionic liquid salts and $5 \mathrm{wt} \%$ methanol. The HLVE data for pure water system in presence of $5 \mathrm{wt} \%$ methanol was obtained using CSMHYD ${ }^{61}$. Table 5, Shows $\mathrm{CH}_{4} \mathrm{HLVE}_{\text {data }}$ points experimentally obtained in the Artificial Sea Water (ASW) (5 wt $\% \mathrm{NaCl}$ ).

Thermodynamic hydrate inhibition (THI). The thermodynamic analysis (Fig. 4) of ultra pure water and seawater systems indicate that the hydrate dissociates at low-temperature conditions in the seawater systems compared to the ultra pure water system at similar pressure conditions. The ultra pure water $\mathrm{CH}_{4} \mathrm{HLVE}$ curve was suppressed by $3 \mathrm{~K}$ in Qatar seawater and $2 \mathrm{~K}$ in artificial seawater $(5 \mathrm{wt} \% \mathrm{NaCl})$. The ultra pure water $\mathrm{CH}_{4}$ HLVE results were also compared with the Monteray Bay (Off the California coast) seawater (MBSW) $\mathrm{CH}_{4}$ HLVE results $(\mathrm{S}=33.4 \%)$ reported by Dickens and Quinby-Hunt ${ }^{42}$ and synthetic seawater (SSW) $\mathrm{CH}_{4} \mathrm{HLVE}$ results $(\mathrm{S}=36.6 \%, \mathrm{NaCl}=2.43 \mathrm{wt} \%)$ reported by Atik et al. ${ }^{62}$. The ultra pure water $\mathrm{CH}_{4} \mathrm{HLVE}$ curve was suppressed by $1 \mathrm{~K}$ in MBSW and suppressed by $1.5 \mathrm{~K}$ in SSW. Hence, the higher salinity levels may aid in suppressing the hydrate dissociation conditions. These results indicate that the development of a hydrate mitigation strategy based on tests or modeling work conducted merely on a pure water system is not sufficient. The test can be preferably conducted on the actual offshore seawater samples to get a more reliable data set. 


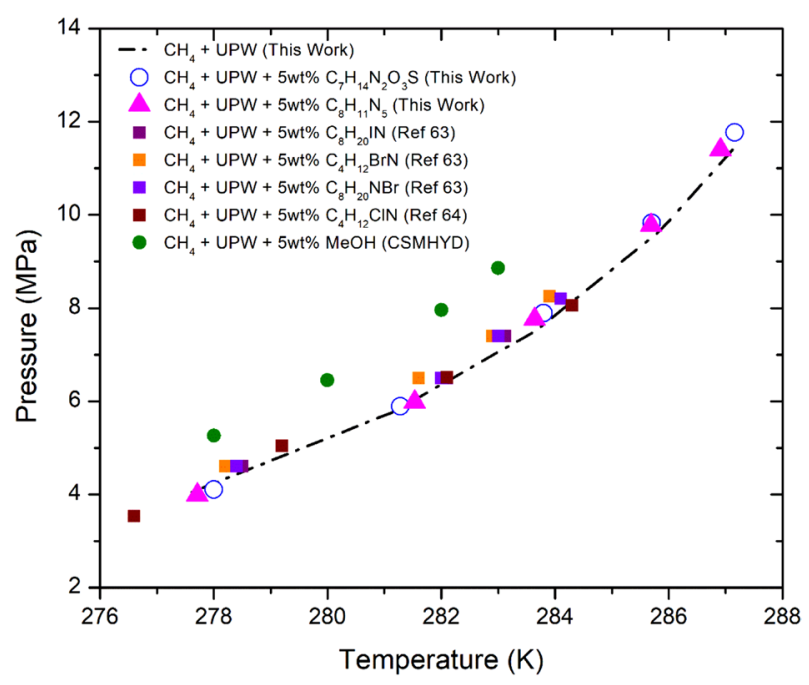

Figure 5. Shift in the ultra pure water $\mathrm{CH}_{4}$ HLVE in the presence of 5wt\% IL salts 3-Ethyl-1-methyl-1Himidazol-3-ium-methane sulfonate $\left[\mathrm{C}_{7} \mathrm{H}_{14} \mathrm{~N}_{2} \mathrm{O}_{3} \mathrm{~S}\right]$, 3-Ethyl-1-methyl-1H-imidazol-3-ium-dicyanoazamide $\left[\mathrm{C}_{8} \mathrm{H}_{11} \mathrm{~N}_{5}\right]$, Tetra-ethyl-ammonium Iodide $\left[\mathrm{C}_{8} \mathrm{H}_{20} \mathrm{IN}\right]^{63}$, Tetra-ethyl-ammonium Bromide $\left[\mathrm{C}_{8} \mathrm{H}_{20} \mathrm{NBr}\right]^{63}$, Tetramethyl-ammonium Bromide $\left[\mathrm{C}_{4} \mathrm{H}_{12} \mathrm{BrN}\right]^{63}$, Tetra-methyl-ammonium Chloride $\left[\mathrm{C}_{4} \mathrm{H}_{12} \mathrm{ClN}\right]^{64}$ and Methanol $[\mathrm{MeOH}]^{61}$. The experimental HLVE data of this work has the uncertainty of about $\pm 0.05 \mathrm{~K}$.

THI effect of lonic liquids in the pure water system and Qatar seawater system. The THI strength of the selected Ionic liquids (ILs) salts, 3-Ethyl-1-methyl-1H-imidazol-3-ium methane-sulfonate $\left[\mathrm{C}_{7} \mathrm{H}_{14} \mathrm{~N}_{2} \mathrm{O}_{3} \mathrm{~S}\right]$ and 3-Ethyl-1-methyl-1H-imidazol-3-ium dicyanoazanide $\left[\mathrm{C}_{8} \mathrm{H}_{11} \mathrm{~N}_{5}\right]$ was evaluated in both the ultra pure water and Qatar seawater systems. In a ultra pure water system, their inhibition performance was compared with methanol and other ammonium ILs salts, Tetra-ethyl-ammonium Iodide $\left[\mathrm{C}_{8} \mathrm{H}_{20} \mathrm{IN}\right]$, Tetraethyl-ammonium Bromide $\left[\mathrm{C}_{8} \mathrm{H}_{20} \mathrm{NBr}\right.$ ], Tetra-methyl-ammonium Bromide $\left[\mathrm{C}_{4} \mathrm{H}_{12} \mathrm{BrN}\right]$, Tetra-methyl-ammonium Chloride $\left[\mathrm{C}_{4} \mathrm{H}_{12} \mathrm{ClN}\right]$ reported by Qasim et al. ${ }^{63}$ and Khan et al. ${ }^{64}$. As shown in Fig. 5, the $5 \mathrm{wt} \%$ ILs salts used in this work and those reported in literature showed no significant THI effect and in comparison, 5wt\% methanol was able to shift the $\mathrm{CH}_{4} \mathrm{HLVE}$ by about $2 \mathrm{~K}$ at all pressure conditions. This indicates that in the case of ILs salts the $5 \mathrm{wt} \%$ dosage may not be sufficient enough to see a significant THI effect. Thus, higher concentration or dosage of ILs salts may be required to enhance their THI effect.

Stark et al. ${ }^{65}$, studied the binary system of water and IL 3-Ethyl-1-methyl-1H-imidazol-3-ium methanesulfonate $\left[\mathrm{C}_{7} \mathrm{H}_{14} \mathrm{~N}_{2} \mathrm{O}_{3} \mathrm{~S}\right]$. They observed that the water molecules do not tightly bound with the selected IL $\left[\mathrm{C}_{7} \mathrm{H}_{14} \mathrm{~N}_{2} \mathrm{O}_{3} \mathrm{~S}\right]$. Their activation energy analysis indicates that there exists a barrier that hinders the translational motion or self-diffusion between ionic liquids anion, cation, and water molecules. This may be preventing the bidding of free water molecules by the IL $\left[\mathrm{C}_{7} \mathrm{H}_{14} \mathrm{~N}_{2} \mathrm{O}_{3} \mathrm{~S}\right]$.

The same experiments with selected $5 \mathrm{wt} \%$ ILs and $5 \mathrm{wt} \%$ methanol were repeated using the seawater system containing the $\mathrm{SO}_{4}{ }^{2-}, \mathrm{Cl}^{-}, \mathrm{Na}^{+}$, and $\mathrm{Mg}^{2+}$ ions. As shown in Fig. 5 , in the ultra pure water system the ILs showed no THI effect. However, in the Qatar seawater system with the dissolved ions the ILs shifted the $\mathrm{CH}_{4} \mathrm{HVLE}$ within the range of $0.4-1.0 \mathrm{~K}$ at the pressure range of 4-12 MPa (Figs. 6, 7). Del Villano and Kelland ${ }^{66}$, reported that some ILs are weak hydrate inhibitors, but both can act as good synergist in the presence of other commercial kinetic inhibitors or salts. Thus, the selected ionic liquids were observed to be weak thermodynamic inhibitors but may tend to act as the synergist in the presence of $\mathrm{SO}_{4}{ }^{2-}, \mathrm{Cl}^{-}, \mathrm{Na}^{+}$, and $\mathrm{Mg}^{2+}$ ions. The salt and ions present in the seawater can also act as hydrate inhibitor themselves and affect the thermodynamic stability of natural gas hydrate. The ions present in the aqueous solution may reduce the chemical potential of liquid water leading to the prevention of hydrate formation.

As shown in Fig. 7, the IL $\left[\mathrm{C}_{7} \mathrm{H}_{14} \mathrm{~N}_{2} \mathrm{O}_{3} \mathrm{~S}\right]$ showed a similar THI effect at variable pressure conditions (8-11 MPa) and provided the temperature shift of about $0.4-0.5 \mathrm{~K}( \pm 0.05 \mathrm{~K})$. In comparison, the IL $\left[\mathrm{C}_{8} \mathrm{H}_{11} \mathrm{~N}_{5}\right]$ provided a better THI effect and provided a temperature shift of about $0.6-0.9 \mathrm{~K}( \pm 0.05 \mathrm{~K})$ within the pressure range of 8-11 MPa. The maximum temperature shift of about $0.9 \mathrm{~K}$ was provided by $\mathrm{IL}\left[\mathrm{C}_{8} \mathrm{H}_{11} \mathrm{~N}_{5}\right]$ at higher pressures of about $10 \mathrm{MPa}$. Thus, the IL $\left[\mathrm{C}_{8} \mathrm{H}_{11} \mathrm{~N}_{5}\right]$ was observed to be slightly more effective than the IL $\left[\mathrm{C}_{7} \mathrm{H}_{14} \mathrm{~N}_{2} \mathrm{O}_{3} \mathrm{~S}\right]$. In comparison, the methanol $\left[\mathrm{CH}_{3} \mathrm{OH}\right]$ provided the temperature shift of about $2-2.5 \mathrm{~K}$ $( \pm 0.05 \mathrm{~K})$. Thus in terms of effectiveness the inhibitors can be listed as: $\mathrm{CH}_{3} \mathrm{OH}>\mathrm{C}_{8} \mathrm{H}_{11} \mathrm{~N}_{5}>\mathrm{C}_{7} \mathrm{H}_{14} \mathrm{~N}_{2} \mathrm{O}_{3} \mathrm{~S}$.

According to You et al. ${ }^{67}$, methane hydrate formation and dissociation are affected by salinity in a closed system. In a closed saline system, during hydrate formation, the salts are separated from hydrate which leads to an increase in the salinity levels of the surrounding fluid. This causes the system to be separated into three equilibrium phases (gas, water, and hydrate phases) and impedes the further formation and growth of hydrate crystals. Saw et al.$^{68}$, investigated the methane hydrate formation and dissociation in the synthetic seawater and observed that the hydrate formation and dissociation strongly rely on the salinity level of the chosen water sample. The hydrate dissociation pressure tends to increase with the increase in the salinity of the synthetic seawater. According to Saw et al. ${ }^{68}$, the solubility of methane in the aqueous solution tends to decreases with the 


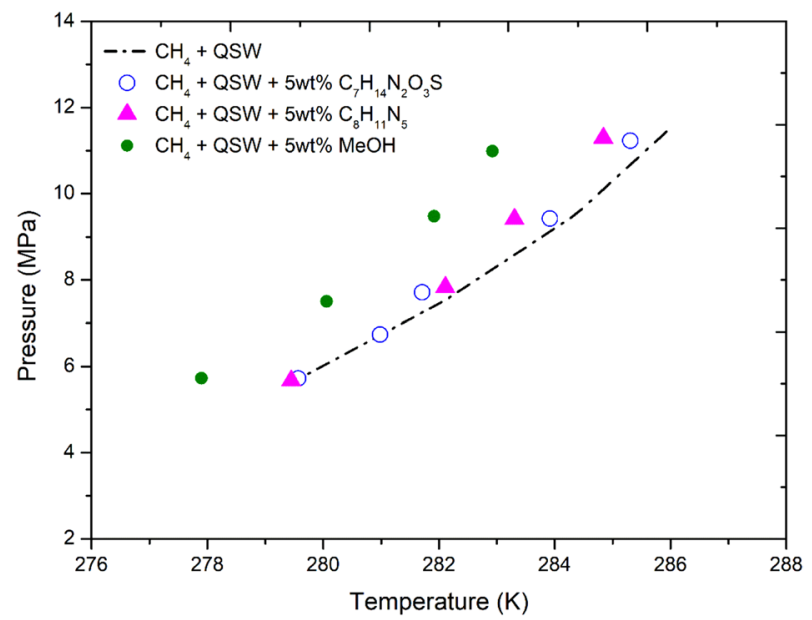

Figure 6. Shift in the Qatar seawater $\mathrm{CH}_{4} \mathrm{HLVE}$ in the presence of $5 \mathrm{wt} \%$ IL salts 3-Ethyl-1-methyl-1Himidazol-3-ium-methane sulfonate $\left[\mathrm{C}_{7} \mathrm{H}_{14} \mathrm{~N}_{2} \mathrm{O}_{3} \mathrm{~S}\right]$, 3-Ethyl-1-methyl-1H-imidazol-3-ium-dicyanoazamide $\left[\mathrm{C}_{8} \mathrm{H}_{11} \mathrm{~N}_{5}\right]$ and Methanol $[\mathrm{MeOH}]$. The experimental HLVE data of this work has the uncertainty of about $\pm 0.05 \mathrm{~K}$.

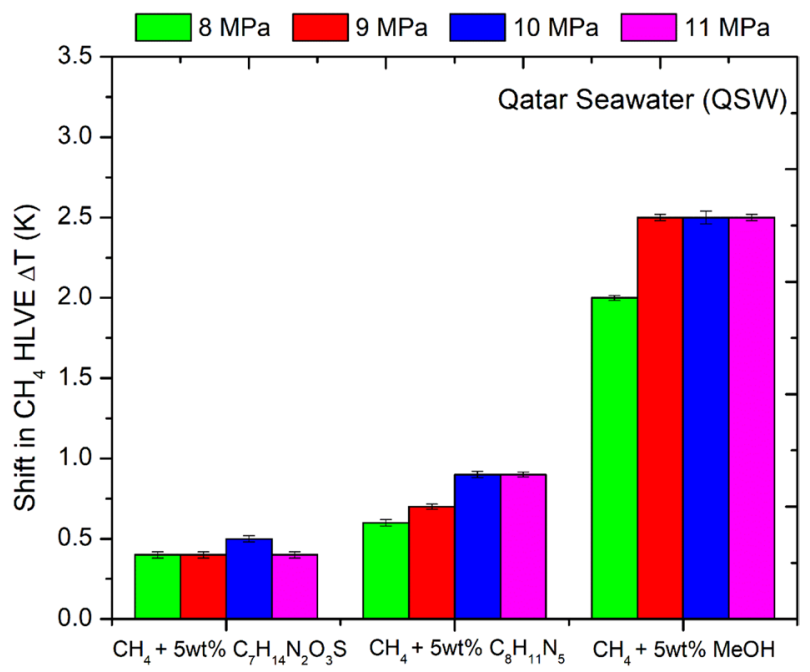

Figure 7. Shift in CH4 HLVE (Qatar seawater) in the presence of $5 \mathrm{wt} \%$ IL salts 3-Ethyl-1-methyl-1H-imidazol3-ium-methane sulfonate $\left[\mathrm{C}_{7} \mathrm{H}_{14} \mathrm{~N}_{2} \mathrm{O}_{3} \mathrm{~S}\right]$, 3-Ethyl-1-methyl-1H-imidazol-3-ium-dicyanoazamide $\left[\mathrm{C}_{8} \mathrm{H}_{11} \mathrm{~N}_{5}\right]$ and Methanol $[\mathrm{MeOH}]$. The standard deviation of $0.01-0.05 \mathrm{~K}$ was calculated for the above data set. The above data has the uncertainty of about $\pm 0.05 \mathrm{~K}$.

increase in the level of salinity may be due to an increasing amount of interactions between dissolved ions and the guest $\mathrm{CH}_{4}$ molecule.

Kinetic hydrate inhibition (KHI). The hydrate induction time is considered to be a good indicator for evaluating the kinetic inhibition strength of the hydrate inhibitors ${ }^{69}$. The hydrate formation time may vary from seconds to days as a result of the complex nature of the hydrate formation process ${ }^{69}$. According to Sloan Jr and $\mathrm{Koh}^{3}$, the hydrate induction time relies on different factors, which include subcooling temperature, water history, impurities, gas composition, and system geometry. Therefore, the hydrate kinetic experiments cannot be replicated and the results obtained from one system may not match with the results of the other system.

In this work, the $\mathrm{CH}_{4}$ hydrate formation kinetics were observed in both ultra pure water and Qatar seawater systems. The hypothetical illustration of $\mathrm{CH}_{4}$ hydrate formation in the ultra pure water and saline water system is shown in Fig. 8. The ions present in the seawater system may affect the activity of water and gas molecules in aqueous solution and are likely to tend to interact with the gas molecule ${ }^{68}$. This likely makes it difficult for the water molecules to encapsulate gas molecules and form a stable hydrate crystal lattice. The dissolved ions in seawater may interact with the water molecular structure via Columbic forces, which may hinder the formation of the gas hydrates. The presence ions may also reduce the availability of free water molecules in the system and may cause electrostatic interactions with the molecules, impeding the formation of gas hydrates ${ }^{70,71}$. 


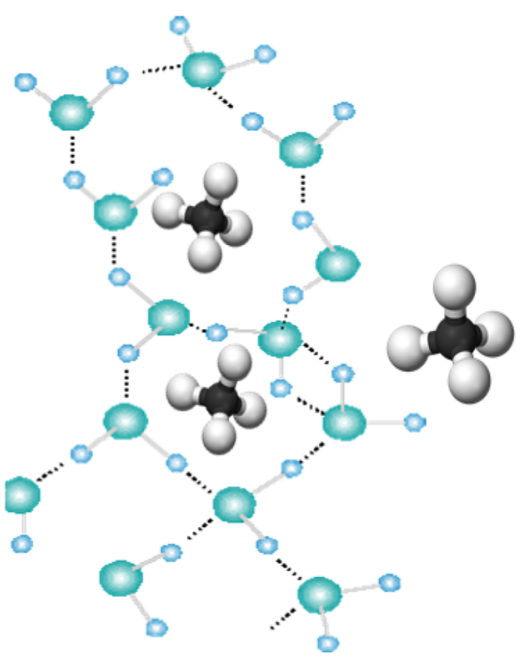

Methane molecule in ultra pure water during hydrate formation

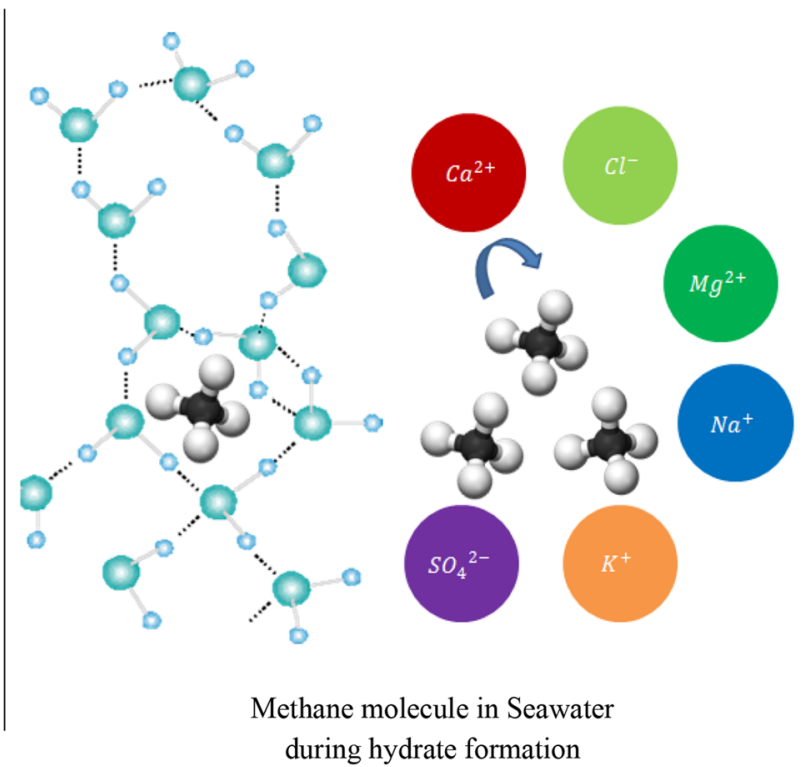

during hydrate formation

Figure 8. The hypothetical illustration of the hydrate formation in the ultra pure water system and the saline water system in the absence of inhibitor.

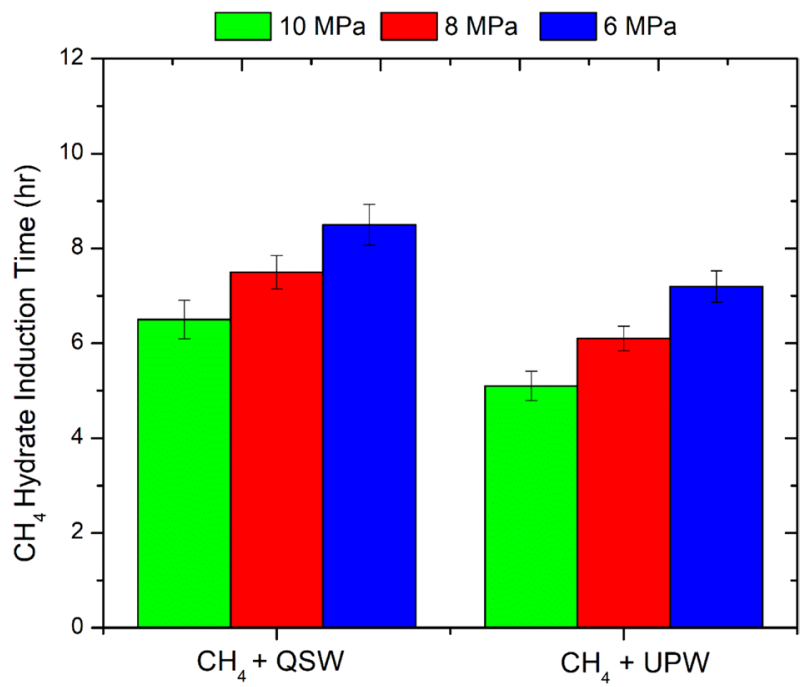

Figure 9. $\mathrm{CH}_{4}$ hydrate induction time in the Qatar seawater (QSW) and ultra pure water (PW) system at different pressure conditions. The above data has an uncertainity of about $\pm 0.33 \mathrm{~h}$.

As shown in Fig. 9, the hydrate induction occurs faster in the ultra pure water system compared to the seawater system. Hydrate induction occurs faster at higher pressures conditions compared to lower pressure conditions. At $6 \mathrm{MPa}$, the hydrate induction time in ultra pure water system was about $7.2 \pm 0.3 \mathrm{~h}$ and in Qatar seawater system it was about $8.5 \pm 0.3 \mathrm{~h}$. Similarly, at $10 \mathrm{MPa}$, the hydrate induction time in ultra pure water system was about $5.1 \pm 0.3 \mathrm{~h}$ and in Qatar seawater system it was about $6.5 \pm 0.3 \mathrm{~h}$. As mentioned above, the delay in hydrate induction time in Qatar seawater system may be due to the presence of the ions in the seawater system that may be interacting with the $\mathrm{CH}_{4}$ molecule and causing re-orientation of the molecule. As a result, the hydrate formation occurs slower in the seawater system compared to the ultra pure water system. Recently, Thakre et al. ${ }^{72}$ examined the methane hydrate formation dynamics in saline water (1:6). They observed that the presence of salt ions results in vapor-liquid-phase separation. Moreover, due to bubble formation, the two-phase gas-liquid system experiences a low density of methane, which retards the hydrate growth rate. They also stated that for low salt dosage $(0.8 \mathrm{wt} \%)$ only slight inhibition effect occurs. However, the inhibition effect gets more significant at higher dosages (1.5-5.0 wt \%) of salt in water. Idress et al. ${ }^{73}$, also stated that the level of salinity significantly impacts gas hydrate induction time and dissociation due to its ability to act as an inhibitor by delaying the nucleation of methane hydrate. Yang and $\mathrm{Xu}^{43}$, highlighted that the thickness of $\mathrm{CH}_{4}$ hydrate becomes thinner in saline/ seawater compared to that of the ultra pure water system. Saw et al. ${ }^{68}$, reported that the hydrate 


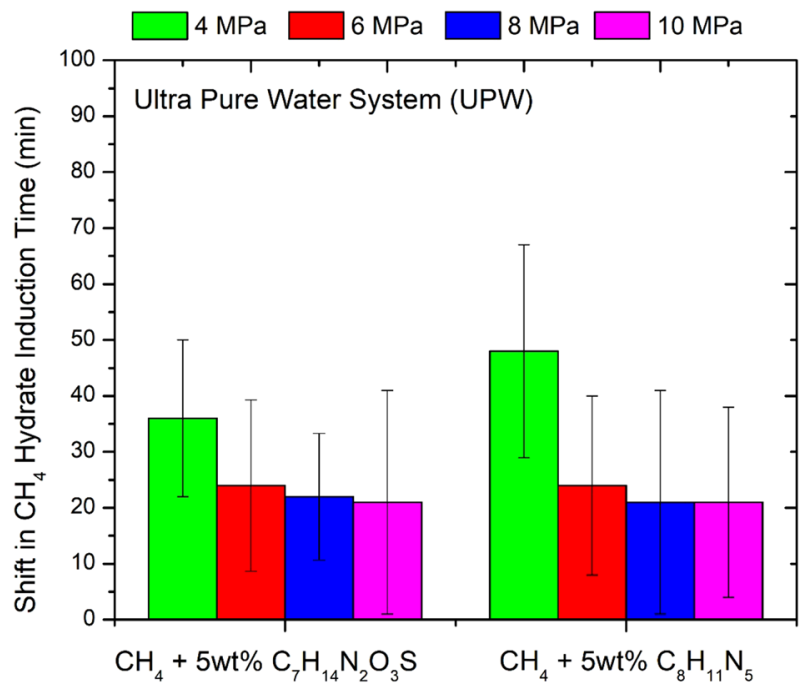

Figure 10. Shift $\mathrm{CH}_{4}$ hydrate induction time (ultra pure water system) in the presence of 5wt\% IL salts, 3-Ethyl1-methyl-1H-imidazol-3-ium-methane sulfonate $\left[\mathrm{C}_{7} \mathrm{H}_{14} \mathrm{~N}_{2} \mathrm{O}_{3} \mathrm{~S}\right]$ and 3-Ethyl-1-methyl-1H-imidazol-3-iumdicyanoazamide $\left[\mathrm{C}_{8} \mathrm{H}_{11} \mathrm{~N}_{5}\right]$. The above data has an uncertainity of about $\pm 0.33 \mathrm{~h}$.

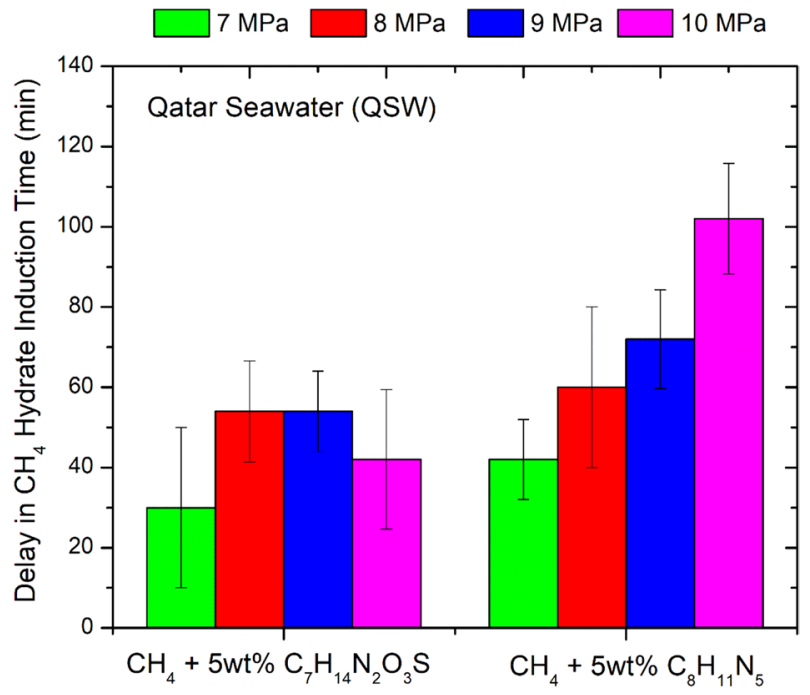

Figure 11. Shift $\mathrm{CH}_{4}$ hydrate induction time (Qatar seawater system) in the presence of 5wt\% IL salts: 3-Ethyl1-methyl-1H-imidazol-3-ium-methane sulfonate $\left[\mathrm{C}_{7} \mathrm{H}_{14} \mathrm{~N}_{2} \mathrm{O}_{3} \mathrm{~S}\right]$ and 3-Ethyl-1-methyl-1H-imidazol-3-iumdicyanoazamide $\left[\mathrm{C}_{8} \mathrm{H}_{11} \mathrm{~N}_{5}\right]$. The above data has an uncertainity of about $\pm 0.33 \mathrm{~h}$.

dissociation enthalpy decreases with the increase in the temperature and salinity of the synthetic seawater, and the hydrate induction or formation times depends on the sub-cooling temperature and the salt concentration present in the selected c seawater sample.

$\mathrm{KHI}$ effect of Ionic liquids in Pure water and Qatar seawater system. Initially, the kinetic inhibition effect of selected ILs on methane hydrate formation in a ultra pure water system was tested at different pressure conditions (4-12 MPa). As shown in Fig. 10, both ILs showed a slight KHI effect and the methane hydrate induction time was delayed by about 36-48 $\mathrm{min}( \pm 20 \mathrm{~min})$ at low pressures $(\sim 4 \mathrm{MPa})$ and by $21 \mathrm{~min}$ $( \pm 20 \mathrm{~min})$ at high pressures $(\sim 10 \mathrm{MPa})$. The maximum time delay of about $48 \mathrm{~min}( \pm 20 \mathrm{~min})$ was provided by the IL $\mathrm{C}_{8} \mathrm{H}_{11} \mathrm{~N}_{5}$ at about $4 \mathrm{MPa}$. In terms of effectiveness as kinetic hydrate inhibitors, the IL $\mathrm{C}_{8} \mathrm{H}_{11} \mathrm{~N}_{5}$ was found to be slightly more effective than IL $\mathrm{C}_{7} \mathrm{H}_{14} \mathrm{~N}_{2} \mathrm{O}_{3} \mathrm{~S}$.

The kinetic inhibition strength of ILs $\mathrm{C}_{8} \mathrm{H}_{11} \mathrm{~N}_{5}$ and $\mathrm{C}_{7} \mathrm{H}_{14} \mathrm{~N}_{2} \mathrm{O}_{3} \mathrm{~S}$ in mitigating methane hydrate formation was then tested in the Qatar seawater system (Fig. 11). In the seawater system, both inhibitors performed slightly better than the ultra pure water system. This improvement in the inhibition effect may be attributed to the presence $\mathrm{SO}_{4}{ }^{2-}, \mathrm{Cl}^{-}, \mathrm{Na}^{+}$and $\mathrm{Mg}^{2+}$ ions in the system that may be leading to a synergistic effect. As shown in Fig. 11, the IL $\mathrm{C}_{8} \mathrm{H}_{11} \mathrm{~N}_{5}$ provides better kinetic inhibition effect compared to IL $\mathrm{C}_{7} \mathrm{H}_{14} \mathrm{~N}_{2} \mathrm{O}_{3} \mathrm{~S}$ again. The maximum time 


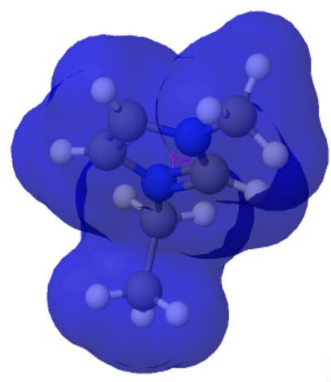

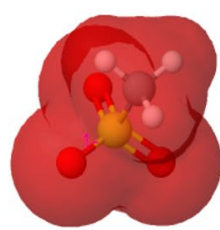

3-Ethyl-1-methyl-1H-imidazol-3-ium-methane sulfonate $\left[\mathrm{C}_{7} \mathrm{H}_{14} \mathrm{~N}_{2} \mathrm{O}_{3} \mathrm{~S}\right]$
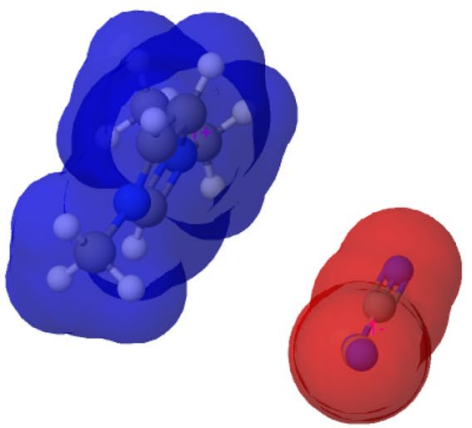

3-Ethyl-1-methyl-1H-imidazol-3-iumdicyanoazamide $\left[\mathrm{C}_{8} \mathrm{H}_{11} \mathrm{~N}_{5}\right]$

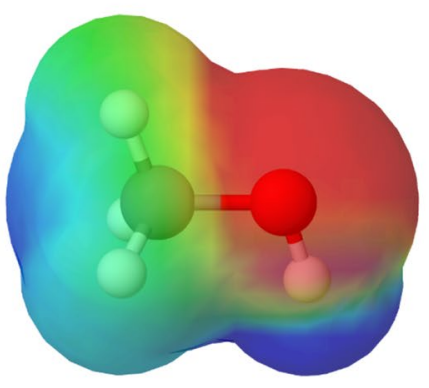

Methanol

Figure 12. 3D computational models of IL salts: 3-Ethyl-1-methyl-1H-imidazol-3-ium-methane sulfonate $\left[\mathrm{C}_{7} \mathrm{H}_{14} \mathrm{~N}_{2} \mathrm{O}_{3} \mathrm{~S}\right]$, 3-Ethyl-1-methyl-1H-imidazol-3-ium-dicyanoazamide $\left[\mathrm{C}_{8} \mathrm{H}_{11} \mathrm{~N}_{5}\right]$ and Methanol [MeOH].

delay of about $102 \mathrm{~min}( \pm 20 \mathrm{~min})$ is provided by the $\mathrm{IL}_{8} \mathrm{H}_{11} \mathrm{~N}_{5}$ at a pressure around $10 \mathrm{MPa}$. At $7 \mathrm{MPa}$, both ILs provided a similar time delay of about $30-42 \mathrm{~min}( \pm 20 \mathrm{~min})$.

In the above context, the both ILs tend to act as the kinetic hydrate inhibitor and can delay the methane hydrate formation by $21-48 \mathrm{~min}( \pm 20 \mathrm{~min})$ in the ultra pure water system and by $30-102 \mathrm{~min}( \pm 20 \mathrm{~min})$ in the Qatar seawater system. The presence of the ions $\mathrm{SO}_{4}{ }^{2-}, \mathrm{Cl}^{-}, \mathrm{Na}^{+}$and $\mathrm{Mg}^{2+}$ ions in the seawater system may be causing a synergistic effect which improves the kinetic inhibition performance of these ILs in the Qatar seawater system.

Probing hydrate inhibition mechanism in the presence of ILs and methanol. The 3D molecular models for the Ionic liquids (ILs) salts 3-Ethyl-1-methyl-1H-imidazol-3-ium methane-sulfonate $\left[\mathrm{C}_{7} \mathrm{H}_{14} \mathrm{~N}_{2} \mathrm{O}_{3} \mathrm{~S}\right]$, 3-Ethyl-1-methyl-1H-imidazol-3-ium dicyanoazanide $\left[\mathrm{C}_{8} \mathrm{H}_{11} \mathrm{~N}_{5}\right]$ and methanol $\left[\mathrm{CH}_{3} \mathrm{OH}\right]$ were generated using the Molview ${ }^{74}$. As depicted in Fig. 12, the regions colored in red are the areas of high electron density $(-)$ and the regions colored in blue are the areas of low electron density $(+)$. The disruption of the hydrogen-bonding network within the hydrate clusters occurs due to the strong electrostatic force of interaction between the ILs and the water molecules. Xiao et al. $^{75}$, also stated that the ILs salts have strong electrostatic charges, and simultaneously their anions/cations may form hydrogen bonding with water disrupting the formation of gas hydrates. They also stated that for ILs with the same anion, the THI effect of ILs with shorter alkyl chain substituent is superior to ILs with longer alkyl chain substituent. The THI effectiveness of ILs may also rely on electrical conductivity (EC) of ILs in sample solutions. ILs with higher EC in sample solutions may exhibit higher THI effects. However, it's hydrogen bonding strength of ILs with water that is likely to play a significant role in THI effectiveness of selected ILs.

The molecular electrostatic maps in Fig. 12, facilitates the conception of electron density within the ILs and methanol to spot the regions of high and low electron density. An electrostatic potential map in Fig. 12 depicts that the high electron regions (red color) within the IL are the methane-sulfonate and dicyanoazanide ions. As mentioned above, these ions are likely to disturb the hydrogen bonding within water molecules, and cause a strong electrostatic force of interaction with water molecules, interrupting the hydrate formation process. The methanol has -OH groups, as shown in Fig. 12, which may help it to provide a better THI effect compared to the ILs. The strong interfacial-interactions of the $-\mathrm{OH}$ group with the hydrogen bonds in the hydrate structure may cause strong disruption or disorientation within the hydrate crystal structure. Vojta and Vazdar ${ }^{76}$, also stated that the crucial element that aids methanol in exhibiting better THI effect is the existence of the $-\mathrm{OH}$ group. The strong interface of $-\mathrm{OH}$ group with the hydrogen bonds in hydrates and further interface of $-\mathrm{CH}_{3}$ group with the $\mathrm{C}-\mathrm{C}$ or hydrogen bonds within hydrates tend to cause disruption of hydrate crystals ${ }^{76}$. The presence of $-\mathrm{OH}$ 
group is may also play a key role in making hydrogen bonds with water molecules and shifting the thermodynamic equilibrium through hydrogen bonding.

\section{Conclusions}

In this work, the $\mathrm{CH}_{4}$ HLVE data in ultra pure water system was compared with CH4 HLVE data in artificial seawater (ASW), Qatar seawater (QSW), and other saline water systems reported in the literature. The $\mathrm{CH}_{4}$ pure water HLVE curve was suppressed by about $3 \mathrm{~K}$ in Qatar seawater and $2 \mathrm{~K}$ in artificial seawater. The hydrate inhibition performance of the Ionic liquids (ILs) salts $\mathrm{C}_{7} \mathrm{H}_{14} \mathrm{~N}_{2} \mathrm{O}_{3} \mathrm{~S}$ and $\mathrm{C}_{8} \mathrm{H}_{11} \mathrm{~N}_{5}$ was evaluated in the ultra pure water system and Qatar seawater systems at different pressure conditions (4-12 MPa) and their performance was compared with industrial thermodynamic inhibitor methanol and other ILs salts reported in the literature.

The selected ILs exhibited poor hydrate inhibition effect in the ultra pure water systems, but they show a noticeable thermodynamic and kinetic hydrate inhibition effect in the Qatar seawater system. The IL salt $\mathrm{C}_{8} \mathrm{H}_{11} \mathrm{~N}_{5}$ exhibited slightly better hydrate inhibition performance than the IL $\mathrm{C}_{7} \mathrm{H}_{14} \mathrm{~N}_{2} \mathrm{O}_{3} \mathrm{~S}$. However, in comparison to methanol, the hydrate inhibition provided by IL salts was not significant in the ultra pure water system and Qatar seawater system both. The better performance of IL salts in Qatar seawater indicates that the presence of dissolved salt ions in the seawater like $\mathrm{SO}_{4}{ }^{2-}, \mathrm{Cl}^{-}, \mathrm{Na}^{+}$and $\mathrm{Mg}^{2+}$ ions helps to improve the thermodynamic inhibition effect of ILs and may lead to a synergistic effect. This work indicates that developing a hydrate mitigation strategy merely on the HLVE data set obtained using a pure water sample is not adequate and actual offshore seawater samples need to be considered. The selected ILs in this work do not exhibit a significant THI effect in comparison to methanol. However, they can delay the hydrate induction time, a benefit that the conventional THI does not offer. This can be considered a step forward in the search of better THI that can be tailored according to the process required and at the same time are environmentally benign. In the future, similar work needs to be conducted using the actual Qatar natural gas mixture and actual offshore Qatar seawater sample. This will help to get a more reliable set of data for the development of a hydrate mitigation strategy for offshore flow assurance.

Received: 20 June 2020; Accepted: 16 October 2020

Published online: 10 November 2020

\section{References}

1. Sloan, E. D. Fundamental principles and applications of natural gas hydrates. Nature 426, 353-363 (2003).

2. Zheng, J., Chong, Z. R., Qureshi, M. F. \& Linga, P. Carbon dioxide sequestration via gas hydrates: a potential pathway toward decarbonization. Energy Fuels https://doi.org/10.1021/acs.energyfuels.0c02309 (2020).

3. Sloan Jr, E. D. \& Koh, C. Clathrate hydrates of natural gases. (CRC press, 2007).

4. Rasul, G. et al. Analysis of Cuttings Transport and Flow Pattern in Nearly Horizontal Extended Reach Well.

5. Qureshi, M. F. et al. in SPE Kuwait Oil \& Gas Show and Conference. (Society of Petroleum Engineers).

6. Atilhan, M. \& Aparicio, S. Review on Natural Gas Thermopysical Property Measurement Techniques. (INTECH Open Access Publisher, 2012).

7. Altamash, T. et al. Gas hydrates inhibition via combined biomolecules and synergistic materials at wide process conditions. J. Nat. Gas Sci. Eng. 46, 873-883 (2017).

8. Dargin, J. Qatar's natural gas: the foreign-policy driver. Middle East Policy 14, 136 (2007).

9. Max, M. D. Natural gas hydrate in oceanic and permafrost environments. Vol. 5 (Springer Science \& Business Media, 2003).

10. Xiao, C. \& Adidharma, H. Dual function inhibitors for methane hydrate. Chem. Eng. Sci. 64, 1522-1527 (2009).

11. Kelland, M. A. History of the development of low dosage hydrate inhibitors. Energy Fuels 20, 825-847 (2006).

12. Azizi, A. et al. Effect of hydrate anti-agglomerants on water-in-crude oil emulsion stability. J. Pet. Explor. Prod. Technol. 10, 139-148. https://doi.org/10.1007/s13202-019-0691-0 (2020).

13. Qureshi, M. F. et al. Gas hydrate prevention and flow assurance by using mixtures of ionic liquids and synergent compounds: combined kinetics and thermodynamic approach. Energy Fuels 30, 3541-3548 (2016).

14. Teixeira, A. M., de Oliveira Arinelli, L., de Medeiros, J. L. \& Ofélia de Queiroz, F. A. Exergy analysis of monoethylene glycol recovery processes for hydrate inhibition in offshore natural gas fields. J. Nat. Gas Sci. Eng. 35, 798-813 (2016).

15. Perrin, A., Musa, O. M. \& Steed, J. W. The chemistry of low dosage clathrate hydrate inhibitors. Chem. Soc. Rev. 42, 1996-2015 (2013).

16. Bates, E. D., Mayton, R. D., Ntai, I. \& Davis, J. H. CO2 capture by a task-specific ionic liquid. J. Am. Chem. Soc. 124, 926-927 (2002).

17. Zhang, X. et al. Carbon capture with ionic liquids: overview and progress. Energy Environ. Sci. 5, 6668-6681 (2012).

18. Stolte, S. et al. Primary biodegradation of ionic liquid cations, identification of degradation products of 1-methyl-3-octylimidazolium chloride and electrochemical wastewater treatment of poorly biodegradable compounds. Green Chem. 10, 214-224 (2008).

19. Werner, S., Haumann, M. \& Wasserscheid, P. Ionic liquids in chemical engineering. Annu. Rev. Chem. Biomol. Eng. 1, 203-230 (2010).

20. Wishart, J. F. Energy applications of ionic liquids. Energy Environ. Sci. 2, 956-961 (2009).

21. Bara, J. E. et al. Synthesis and performance of polymerizable room-temperature ionic liquids as gas separation membranes. Ind. Eng. Chem. Res. 46, 5397-5404 (2007).

22. Chong, F. K., Foo, D. C., Eljack, F. T., Atilhan, M. \& Chemmangattuvalappil, N. G. Ionic liquid design for enhanced carbon dioxide capture by computer-aided molecular design approach. Clean Technol. Environ. Policy 17, 1301-1312 (2015).

23. Kazi, M.-K., Eljack, F., Elsayed, N. A. \& El-Halwagi, M. M. Integration of energy and wastewater treatment alternatives with process facilities to manage industrial flares during normal and abnormal operations: multiobjective extendible optimization framework. Ind. Eng. Chem. Res. 55, 2020-2034 (2016).

24. Karadas, F., Atilhan, M. \& Aparicio, S. Review on the use of ionic liquids (ILs) as alternative fluids for $\mathrm{CO} 2$ capture and natural gas sweetening. Energy Fuels 24, 5817-5828 (2010).

25. Aparicio, S., Atilhan, M. \& Karadas, F. Thermophysical properties of pure ionic liquids: review of present situation. Ind. Eng. Chem. Res. 49, 9580-9595 (2010).

26. Bandrés, I., Alcalde, R., Lafuente, C., Atilhan, M. \& Aparicio, S. On the viscosity of pyridinium based ionic liquids: an experimental and computational study. J. Phys. Chem. B 115, 12499-12513 (2011).

27. Aparicio, S., Atilhan, M., Khraisheh, M., Alcalde, R. \& Fernández, J. Study on hydroxylammonium-based ionic liquids. II. Computational analysis of CO2 absorption. J. Phys. Chem. B 115, 12487-12498 (2011). 
28. Atilhan, M., Jacquemin, J., Rooney, D., Khraisheh, M. \& Aparicio, S. Viscous behavior of imidazolium-based ionic liquids. Ind. Eng. Chem. Res. 52, 16774-16785 (2013).

29. Sanz, V., Alcalde, R., Atilhan, M. \& Aparicio, S. Insights from quantum chemistry into piperazine-based ionic liquids and their behavior with regard to CO2. J. Mol. Model. 20, 1-14 (2014).

30. García, G., Atilhan, M. \& Aparicio, S. Theoretical study on the solvation of C60 fullerene by ionic liquids. J. Phys. Chem. B 118, $11330-11340$ (2014).

31. Wasserscheid, P. \& Welton, T. Ionic liquids in synthesis. Vol. 1 (Wiley Online Library, 2008).

32. Welton, T. Room-temperature ionic liquids. Solvents for synthesis and catalysis. Chem. Rev. 99, 2071-2084 (1999).

33. Anderson, J. L., Dixon, J. K. \& Brennecke, J. F. Solubility of CO2, CH4, C2H6, C2H4, O2, and N2 in 1-Hexyl-3-methylpyridinium Bis (trifluoromethylsulfonyl) imide: Comparison to Other Ionic Liquids. Acc. Chem. Res. 40, 1208-1216 (2007).

34. Singh, G. \& Kumar, A (Physico-chemical, solvent properties and their applications in chemical processes, Ionic liquids, 2008).

35. Qureshi, M. F., Khraisheh, M. \& Almomani, F. Doping amino acids with classical gas hydrate inhibitors to facilitate the hydrate inhibition effect at low dosages (Science and Technology, Greenhouse Gases, 2020).

36. Rouher, O. S. \& Barduhn, A. J. Hydrates of iso-and normal butane and their mixtures. Desalination 6, 57-73 (1969).

37. Ohgaki, K., Makihara, Y. \& Takano, K. Formation of CO2 hydrate in pure and sea waters. J. Chem. Eng. Jpn. 26, 558-564 (1993).

38. Englezos, P. \& Bishnoi, P. Prediction of gas hydrate formation conditions in aqueous electrolyte solutions. AIChE J. 34, 1718-1721 (1988).

39. Dholabhai, P., Englezos, P., Kalogerakis, N. \& Bishnoi, P. Equilibrium conditions for methane hydrate formation in aqueous mixed electrolyte solutions. Can. J. Chem. Eng. 69, 800-805 (1991).

40. Tishchenko, P., Hensen, C., Wallmann, K. \& Wong, C. S. Calculation of the stability and solubility of methane hydrate in seawater. Chem. Geol. 219, 37-52 (2005).

41. Maekawa, T., Itoh, S., Sakata, S., Igari, S.-I. \& Imai, N. Pressure and temperature conditions for methane hydrate dissociation in sodium chloride solutions. Geochem. J. 29, 325-329 (1995).

42. Dickens, G. R. \& Quinby-Hunt, M. S. Methane hydrate stability in seawater. Geophys. Res. Lett. 21, 2115-2118 (1994).

43. Yang, D. \& Xu, W. Effects of salinity on methane gas hydrate system. Sci. China Ser. D Earth Sci. 50, 1733-1745. https://doi. org/10.1007/s11430-007-0126-5 (2007).

44. Li, S. et al. Experimental measurement and thermodynamic modeling of methane hydrate phase equilibria in the presence of chloride salts. Chem. Eng. J. 395, 125126. https://doi.org/10.1016/j.cej.2020.125126 (2020).

45. Hu, Y., Lee, B. R. \& Sum, A. K. Universal correlation for gas hydrates suppression temperature of inhibited systems: II Mixed salts and structure type. AIChE J. 64, 2240-2250 (2018).

46. Khan, M. N., Peters, C. J. \& Koh, C. A. Desalination using gas hydrates: the role of crystal nucleation, growth and separation. Desalination 468, 114049. https://doi.org/10.1016/j.desal.2019.06.015 (2019).

47. Husebø, J., Ersland, G., Graue, A. \& Kvamme, B. Effects of salinity on hydrate stability and implications for storage of $\mathrm{CO} 2$ in natural gas hydrate reservoirs. Energy Proc. 1, 3731-3738 (2009).

48. Altamash, T., Khraisheh, M. \& Qureshi, M. F. Investigating the effects of mixing ionic liquids on their density, decomposition temperature, and gas absorption. Chem. Eng. Res. Des. 148, 251-259. https://doi.org/10.1016/j.cherd.2019.06.028 (2019).

49. Altamash, T. et al. Cost-effective alkylammonium formate-based protic ionic liquids for methane hydrate inhibition. J. Nat. Gas Sci. Eng. https://doi.org/10.1016/j.jngse.2018.08.002 (2018).

50. Qureshi, F., Gharbi, O. \& Julien, P. in Abu Dhabi International Petroleum Exhibition and Conference. (Society of Petroleum Engineers).

51. Tariq, M. et al. Experimental and DFT approach on the determination of natural gas hydrate equilibrium with the use of excess N2 and choline chloride ionic liquid as an inhibitor. Energy Fuels 30, 2821-2832 (2016).

52. Tariq, M. et al. Doubly dual nature of ammonium-based ionic liquids for methane hydrates probed by rocking-rig assembly. RSC Adv. 6, 23827-23836 (2016).

53. Kelland, M. A., Moi, N. \& Howarth, M. Breakthrough in synergists for kinetic hydrate inhibitor polymers, hexaalkylguanidinium salts: tetrahydrofuran hydrate crystal growth inhibition and synergism with polyvinylcaprolactam. Energy Fuels 27, 711-716 (2013).

54. Daraboina, N., Malmos, C. \& von Solms, N. Synergistic kinetic inhibition of natural gas hydrate formation. Fuel 108, 749-757 (2013).

55. Qureshi, M. Prospects Of Amino Acids And Ionic Liquids As Natural Gas Hydrate Inhibitors For Offshore Flow Assurance, (2018).

56. Tohidi, B., Burgass, R., Danesh, A., Østergaard, K. \& Todd, A. Improving the accuracy of gas hydrate dissociation point measurements. Ann. N. Y. Acad. Sci. 912, 924-931 (2000).

57. Kiyono, F., Tajima, H., Ogasawara, K. \& Yamasaki, A. Method for predicting the dissociation condition of a simple hydrate phase on an H-Lw-V line in isochoric operation. Fluid Phase Equilib. 235, 112-121. https://doi.org/10.1016/j.fluid.2005.07.004 (2005).

58. Kashchiev, D., Verdoes, D. \& Van Rosmalen, G. Induction time and metastability limit in new phase formation. J. Cryst. Growth 110, 373-380 (1991).

59. Chen, L.-T., Sun, C.-Y., Chen, G.-J., Zuo, J. Y. \& Ng, H.-J. Assessment of hydrate kinetic inhibitors with visual observations. Fluid Phase Equilib. 298, 143-149 (2010).

60. Qureshi, M. F. et al. High-pressure gas hydrate autoclave hydraulic experiments and scale-up modeling on the effect of stirring RPM effect. J. Nat. Gas Sci. Eng. 38, 50-58 (2017).

61. Sloan, E. The Colorado School of Mines hydrate prediction program CSMHYD (Centre for Hydrate Research, Colorado School of Mines, 1996).

62. Atik, Z., Windmeier, C. \& Oellrich, L. R. Experimental and theoretical study on gas hydrate phase equilibria in seawater. J. Chem. Eng. Data 55, 804-807 (2010).

63. Qasim, A., Khan, M. S., Lal, B., Ismail, M. C. \& Rostani, K. Quaternary ammonium salts as thermodynamic hydrate inhibitors in the presence and absence of monoethylene glycol for methane hydrates. Fuel 259, 116219. https://doi.org/10.1016/j.fuel.2019.11621 $9(2020)$.

64. Khan, M. S., Lal, B., Keong, L. K. \& Ahmed, I. Tetramethyl ammonium chloride as dual functional inhibitor for methane and carbon dioxide hydrates. Fuel 236, 251-263. https://doi.org/10.1016/j.fuel.2018.09.001 (2019).

65. Stark, A., Zidell, A. W. \& Hoffmann, M. M. Is the ionic liquid 1-ethyl-3-methylimidazolium methanesulfonate [emim] [MeSO3] capable of rigidly binding water?. J. Mol. Liq. 160, 166-179. https://doi.org/10.1016/j.molliq.2011.03.014 (2011).

66. Del Villano, L. \& Kelland, M. A. An investigation into the kinetic hydrate inhibitor properties of two imidazolium-based ionic liquids on Structure II gas hydrate. Chem. Eng. Sci. 65, 5366-5372 (2010).

67. You, K., Kneafsey, T. J., Flemings, P. B., Polito, P. \& Bryant, S. L. Salinity-buffered methane hydrate formation and dissociation in gas-rich systems. J. Geophys. Res. Solid Earth 120, 643-661 (2015).

68. Saw, V. K., Ahmad, I., Mandal, A., Udayabhanu, G. \& Laik, S. Methane hydrate formation and dissociation in synthetic seawater. J. Nat. Gas Chem. 21, 625-632 (2012).

69. Ripmeester, J. A. \& Alavi, S. Molecular simulations of methane hydrate nucleation. ChemPhysChem 11, 978-980 (2010).

70. Riyazuddeen, A., \& Altamash, T. Study of interactions of l-histidine/l-glutamic acid/l-tryptophan/glycylglycine with $\mathrm{KCl} / \mathrm{KNO} 3$ at different temperatures: 298.15, 303.15, 308.15, 313.15, 318.15, 323.15K. Thermochim. Acta 501, 72-77. https://doi.org/10.1016/j. tca.2010.01.012 (2010) 
71. Riyazuddeen, A., Altamash, T. \& Coronas, A. Interactions in 1-histidine/l-glutamic acid/l-tryptophan/glycylglycine +2 mol L-1 aqueous $\mathrm{KCl} / \mathrm{KNO} 3$ systems at different temperatures: an isothermal compressibility study. Thermochim. Acta 543, 313-317. https ://doi.org/10.1016/j.tca.2012.06.006 (2012).

72. Thakre, N., Palodkar, A. V., Dongre, H. J. \& Jana, A. K. Microscopic molecular insights into hydrate formation and growth in pure and saline water environments. J. Phys. Chem. A 124, 4241-4252. https://doi.org/10.1021/acs.jpca.0c00621 (2020).

73. Idress, M., Jasamai, M. \& Syimir Afandi, M. Modelling on gas hydrate kinetics in presence of saline water in porous media. Mater. Today Proc. 5, 21682-21689. https://doi.org/10.1016/j.matpr.2018.07.019 (2018).

74. Smith, T. J. MolView: a program for analyzing and displaying atomic structures on the Macintosh personal computer. J. Mol. Graph. 13, 122-125 (1995).

75. Xiao, C., Wibisono, N. \& Adidharma, H. Dialkylimidazolium halide ionic liquids as dual function inhibitors for methane hydrate. Chem. Eng. Sci. 65, 3080-3087. https://doi.org/10.1016/j.ces.2010.01.033 (2010).

76. Vojta, D. \& Vazdar, M. The study of hydrogen bonding and picdots, three dots, centeredpi interactions in phenolcdots, three dots, centeredethynylbenzene complex by IR spectroscopy. Spectrochim. Acta A Mol. Biomol. Spectrosc. 132, 6-14. https://doi. org/10.1016/j.saa.2014.04.149 (2014).

77. Tumba, K. et al. Phase equilibria of methane and carbon dioxide clathrate hydrates in the presence of aqueous solutions of tributylmethylphosphonium methylsulfate ionic liquid. J. Chem. Eng. Data 56, 3620-3629. https://doi.org/10.1021/je200462q (2011).

\section{Acknowledgements}

The authors would like to acknowledge Qatar University internal funding IRCC-2020-016.

\section{Author contributions}

The paper is a result of a lead PI project lead by Dr. M.K. and her team. Dr. M.F.Q. for experimental work and data analysis contributed to the preparation of the materials and established the experimental protocol. Dr. M.K. is responsible for the full draft of the paper and analysis of the data. Dr F.A. was responsible for main part of the discussion and construction of the figures and tables.

\section{Competing interests}

The authors declare no competing interests.

\section{Additional information}

Correspondence and requests for materials should be addressed to M.K.

Reprints and permissions information is available at www.nature.com/reprints.

Publisher's note Springer Nature remains neutral with regard to jurisdictional claims in published maps and institutional affiliations.

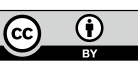

Open Access This article is licensed under a Creative Commons Attribution 4.0 International License, which permits use, sharing, adaptation, distribution and reproduction in any medium or format, as long as you give appropriate credit to the original author(s) and the source, provide a link to the Creative Commons licence, and indicate if changes were made. The images or other third party material in this article are included in the article's Creative Commons licence, unless indicated otherwise in a credit line to the material. If material is not included in the article's Creative Commons licence and your intended use is not permitted by statutory regulation or exceeds the permitted use, you will need to obtain permission directly from the copyright holder. To view a copy of this licence, visit http://creativecommons.org/licenses/by/4.0/. 